\title{
Lihanautojen valkuaisruokinnan optimointi kokoviljasäilörehuruokinnalla
}

\author{
Arto Huuskonen \\ Maa- ja elintarviketalouden tutkimuskeskus, Kotieläintuotannon tutkimus, Tutkimusasemantie 15, \\ 92400 Ruukki,arto.huuskonen@mtt.fi
}

\section{Tiivistelmä}

Tutkimuksen tavoitteena oli selvittää valkuaislisän merkitystä maitorotuisten sonnien kokoviljasäilörehuruokinnalla. Koe-eläimet (36 kpl maitorotuisia sonneja) olivat ruokintakokeen alkaessa keskimäärin 217 vuorokauden ikäisiä. Sonnit jaettiin kokeen alussa elopainon ja rodun perusteella yhdeksään neljän eläimen blokkiin, joista ne edelleen arvottiin neljälle koeruokinnalle.

Ryhmän 1 sonnit saivat vapaasti seosrehua, jossa oli kokoviljasäilörehua (60\% kuiva-aineesta) ja litistettyä ohraa (40 \% kuiva-aineesta). Ryhmä ei saanut valkuaistäydennystä. Ryhmän 2 sonnit ruokittiin muutoin kuten ryhmä 1 mutta sonneilla oli valkuaistäydennyksenä rypsipohjainen KronoTiiviste 35. Tiivisteen annostelumäärä oli kokeen aikana keskimäärin $620 \mathrm{~g} / \mathrm{eläin/vrk.} \mathrm{Tiiviste} \mathrm{korvasi}$ vastaavan määrän litistettyä ohraa sonnien päiväannoksessa. Ryhmän 3 sonnit ruokittiin muutoin kuten ryhmä 1 mutta sonneilla oli valkuaistäydennyksenä Krono-Tiiviste 45, jossa oli käytetty valkuaisena rypsin lisäksi rehu-ureaa. Tiivisteen annostelu toteutettiin siten, että raakavalkuaislisäys (g/pv) oli sama kuin ryhmän 2 eläimillä. Annostelumäärä oli tällöin $480 \mathrm{~g} / \mathrm{eläin/vrk} \mathrm{keskimäärin} \mathrm{kokeen} \mathrm{aikana.}$ Tiiviste korvasi vastaavan määrän litistettyä ohraa sonnien päiväannoksessa. Ryhmän 4 sonnit toimivat kontrollikäsittelynä, ja ne ruokittiin seosrehulla, jossa oli nurmisäilörehua (60 \% kuiva-aineesta) ja litistettyä ohraa (40\% kuiva-aineesta). Ryhmä ei saanut valkuaistäydennystä.

Kokeessa käytetty nurmisäilörehu oli ravitsemukselliselta koostumukseltaan hyvälaatuista. Se sisälsi muuntokelpoista energiaa $10,8 \mathrm{MJ} / \mathrm{kg} \mathrm{ka}$, raakavalkuaista $151 \mathrm{~g} / \mathrm{kg}$ ka ja NDF-kuitua $581 \mathrm{~g} / \mathrm{kg}$ ka. Kokoviljasäilörehun raakavalkuaispitoisuus oli $30 \%$, NDF-pitoisuus $17 \%$ ja energia-arvo $10 \%$ matalampi kuin nurmisäilörehulla.

Sonnien kasvutulokset olivat nurmisäilörehuruokinnalla 6-8 \% paremmat kuin kokoviljasäilörehuruokinnoilla. Kasvuerot olivat todennäköisesti suurimmaksi osaksi seurausta nurmisäilörehusonnien suuremmasta energian saannista, mikä selittyi kokoviljasäilörehun nurmisäilörehua heikommalla sulavuudella. Myös kokoviljasäilörehuruokinnoilla saavutettiin tässä tutkimuksessa hyvät kasvutulokset (nettokasvu keskimäärin $618 \mathrm{~g} / \mathrm{pv}$ ), mikä osoittaa kokoviljasäilörehun olevan varteenotettava vaihtoehto lihanautatilan rehuviljelyssä. Tutkimushypoteesin vastaisesti valkuaistäydennys ei parantanut sonnien kasvua kokoviljasäilörehuruokinnalla. Lisääntynyt raakavalkuaisen saanti ja dieetin korkeampi PVT-arvo valkuaistäydennystä saaneilla ruokinnoilla ei realisoitunut parempina kasvuvasteina, vaikka kokoviljasäilörehuruokinnan PVT-arvo oli ilman valkuaislisää nykyisiä suomalaisia lihanautojen ruokintasuosituksia alemmalla tasolla. Tulosten perusteella maitorotuisten sonnien valkuaisen saanti on riittävä, kun rehuannoksen PVT on yli $-20 \mathrm{~g} / \mathrm{kg}$ ka ja dieetin raakavalkuaispitoisuus yli 110 $\mathrm{g} / \mathrm{kg} \mathrm{ka}$. Valkuaistäydennyksen laadulla (tavanomainen vs. ureapitoinen) ei ollut vaikutusta tuotantotuloksiin.

Asiasanat: naudanlihantuotanto, sonnit, ruokinta, kokoviljasäilörehu, valkuainen, kasvu, syönti, ruhon laatu 


\section{Johdanto}

Tässä raportoitavalla ruokintakokeella haluttiin selvittää valkuaistäydennyksen merkitystä maitorotuisten sonnien ohrakokoviljasäilörehuruokinnalla, kun valkuaistäydennyksenä käytettiin joko tavanomaista (rypsirouhe) tai ureapitoista valkuaistiivistettä. Lisäksi testattiin kokoviljasäilörehuruokintojen tuotantovaikutusta nurmisäilörehupohjaiseen ruokintaan verrattuna.

\section{Aineisto ja menetelmät}

Ruokintakoe suoritettiin MTT:n Siikajoen toimipisteessä. Koe alkoi tammikuussa 2012 ja loppui helmikuussa 2013. Koe-eläimet (36 kpl maitorotuisia sonneja) oli hankittu ternivasikoina A-Tuottajat Oy:n eläinvälityksestä ja välikasvatettu MTT Siikajoen toimipisteessä. Ruokintakokeen alkaessa sonnit olivat keskimäärin $217( \pm 11.0)$ vuorokauden ikäisiä. Sonnit kasvatettiin parsinavetassa, jolloin saatiin eläinkohtaisia havaintoja. Sonnit jaettiin kokeen alussa niiden elopainon ja rodun perusteella yhdeksään neljän eläimen blokkiin (7 ayrshire-blokkia ja 2 holstein-friisiläis-blokkia), joista ne edelleen arvottiin neljälle eri koeruokinnalle. Koeryhmät olivat seuraavat:

1. Sonnit saivat vapaasti seosrehua, jossa oli kokoviljasäilörehua (60\% kuiva-aineesta) ja litistettyä ohraa (40 \% kuiva-aineesta). Lisäksi eläimille annettiin tarvittavat kivennäiset ja vitamiinit. Ryhmän sonnit eivät saaneet valkuaistäydennystä. Ryhmän lyhenne: WCB.

2. Ruokinta muutoin kuin ryhmällä 1 mutta sonneilla oli valkuaistäydennyksenä rypsipohjainen Krono-Tiiviste 35. Tiivisteen annostelumäärä oli $620 \mathrm{~g} / \mathrm{eläin/vrk.} \mathrm{Tiiviste} \mathrm{korvasi} \mathrm{vastaavan}$ määrän litistettyä ohraa sonnien päiväannoksessa. Lisäksi eläimille annettiin tarvittavat kivennäiset ja vitamiinit. Ryhmän lyhenne: WCBRSM.

3. Ruokinta muutoin kuin ryhmällä 1 mutta sonneilla oli valkuaistäydennyksenä Krono-Tiiviste 45 , jossa oli käytetty valkuaisena rypsin lisäksi rehu-ureaa. Tiivisteen annostelu toteutettiin siten, että raakavalkuaislisäys (g/pv) oli sama kuin ryhmän 2 eläimillä. Annostelumäärä oli tällöin $480 \mathrm{~g} / \mathrm{eläin/vrk}$. Tiiviste korvasi vastaavan määän litistettyä ohraa sonnien päiväannoksessa. Eläimille annettiin tarvittavat kivennäiset ja vitamiinit. Ryhmän lyhenne: WCBU.

4. Kontrollina oli seosrehu, jossa oli hyvälaatuista nurmisäilörehua (60 \% kuiva-aineesta) ja litistettyä ohraa (40 \% kuiva-aineesta). Lisäksi eläimille annettiin tarvittavat kivennäiset ja vitamiinit. Ryhmän sonnit eivät saaneet valkuaistäydennystä. Ryhmän lyhenne: GS.

Sonnit ruokittiin koko kokeen ajan edellä mainituilla seosrehuilla, joita ne saivat syödä vapaasti. Ryhmien 1-3 karkearehuna oli taikinatuleentuneesta ohrakasvustosta korjattu kokoviljasäilörehu. Rehu korjattiin suoraan pystykasvustosta niittopäällä varustetulla tarkkuussilppurilla ja säilöttiin laakasiiloon. Säilönnässä käytettiin muurahaishappopohjaista säilöntäainetta (AIV 2 Plus, Kemira Oyj) 5 litraa/tonni tuoretta rehua. Ryhmän 4 karkearehuna oli esikuivattua timotei-nurminata säilörehu, joka oli korjattu noukinvaunulla ja säilötty laakasiiloon. Käytössä oli sekä ensimmäisen että toisen sadon rehua. Nurmisäilörehulla käytettiin samaa säilöntäainetta ja säilöntäaineen annostelumäärää kuin kokoviljasäilörehulla.

Ryhmälle 2 annettu Krono 35 -tiiviste sisälsi rypsirouhetta (753 g/kg ka), melassileikettä (90,5 $\mathrm{g} / \mathrm{kg} \mathrm{ka}$ ), rypsipuristetta (79 g/kg ka), seosmelassia (45 g/kg ka), vehnälesettä ( $20 \mathrm{~g} / \mathrm{kg} \mathrm{ka})$, suolaa (6 $\mathrm{g} / \mathrm{kg} \mathrm{ka})$, kalsiumkarbonaattia (4,5 g/kg ka) ja esiseoksia ( $2 \mathrm{~g} / \mathrm{kg} \mathrm{ka})$. Ryhmän 3 saama Krono 45 tiiviste sisälsi rypsirouhetta ( $578 \mathrm{~g} / \mathrm{kg} \mathrm{ka})$, vehnälesettä ( $239 \mathrm{~g} / \mathrm{kg} \mathrm{ka})$, mäskijauhoa (60 g/kg ka), ureaa (50 g/kg ka), seosmelassia (50 g/kg ka), esiseoksia (8,5 g/kg ka), suolaa (5,5 g/kg ka), kasviöljyä (5 $\mathrm{g} / \mathrm{kg} \mathrm{ka}$ ) ja panimohiivaa (4 g/kg ka). Kaikki eläimet saivat kivennäisseosta (Seleeni Hertta Muro, Suomen Rehu Oy) ja vitamiinivalmistetta (Xylitol ADESAN, Suomen Rehu Oy). Kivennäisseos ja valkuaislisät lisättiin seosrehuun käsin päivittäin ja vitamiinit kerran viikossa.

Aina seosrehua tehtäessä säilörehuista otettiin näytteitä, jotka pakastettiin ja yhdistettiin jokaisen neljän viikon ruokintajakson analyysinäytteeksi. Ohrasta ja valkuaistiivisteistä kerättiin näytteet jokaisesta rehuerästä ja yhdistettiin eräkohtaisiksi analyysinäytteiksi. Säilörehuista ja väkirehuista analysoitiin kuiva-aine, tuhka, raakavalkuainen, neutraalidetergenttikuitu (NDF), raakarasva ja tärkkelys MTT:n laboratoriossa Jokioisilla Huuskosen (2011) kuvaamalla tavalla. Säilörehujen käymislaatu $(\mathrm{pH}$, liukoinen typpi, ammoniumtyppi, vesiliukoiset hiilihydraatit, haihtuvat rasvahapot ja maito- sekä 
muurahaishappo) määritettiin Valio Oy:ssä käytössä olevalla puristenestetitraukseen pohjautuvalla laatumäärityksellä (Moisio \& Heikonen 1989). Säilörehun D-arvo (sulavan orgaanisen aineen pitoisuus kuiva-aineessa) määritettiin Huhtasen ym. (2006) mukaisesti. Rehujen energia- ja valkuaisarvot laskettiin MTT:n (2012) kuvaamalla tavalla. Ruokintojen näennäinen in vivo -sulavuus määritettiin kerran kokeen aikana kaikilta sonneilta käyttäen AIA-menetelmää, jossa käytetään merkkiaineena happoon liukenematonta tuhkaa.

Sonnit teurastettiin kahdessa erässä Atria Oy:n Kauhajoen teurastamossa keskimäärin 562 vuorokauden ikäisinä. Sonnien päiväkasvu laskettiin loppupainon ja kokeen alun painon erotuksena jaettuna kasvatuspäivillä. Nettokasvu laskettiin teuraspainon ja kokeen alun ruhopainon erotuksena jaettuna kasvatuspäivillä. Ruhopainona kokeen alussa käytettiin elopaino $\times 0,5$. Teurastus tapahtui yleisten teurastuskäytäntöjen mukaan ja ruhot luokiteltiin EUROP-luokituksella (EC 2006).

Tulosten tilastollisena käsittelynä tehtiin varianssianalyysi SAS-ohjelmiston GLMproseduurilla. Testauksessa käytetty koe-malli oli: $\mathrm{y}_{\mathrm{ijkl}}=\mu+\beta_{\mathrm{j}}+\gamma_{\mathrm{k}}+\alpha_{\mathrm{i}}+\mathrm{e}_{\mathrm{ijk} \mathrm{kl}}$, missä $\mu$ on yleiskeskiarvo, $\alpha_{\mathrm{i}}$ on koekäsittelyn (ruokinnan) kiinteä vaikutus $(\mathrm{i}=1,2,3,4), \beta_{\mathrm{j}}$ on blokin satunnaisvaikutus $(\mathrm{j}=1, \ldots, 9), \gamma_{\mathrm{k}}$ on teuraserän satunnaisvaikutus $(\mathrm{k}=1,2)$ ja $\mathrm{e}_{\mathrm{ijk} \mathrm{l}}$ on virhetermi. Koekäsittelyjen väliset tilastolliset erot testattiin kontrasteilla. Ensimmäisellä kontrastilla verrattiin nurmisäilörehupohjaista ruokintaa kokoviljasäilörehupohjaisiin ruokintoihin (GS vs. muut). Toisella kontrastilla verrattiin kokoviljasäilörehulla ilman valkuaistäydennystä ruokittuja sonneja valkuaistäydennyksen saaneisiin kokoviljasäilörehusonneihin (WCB vs. WCBRSM + WCBU). Kolmannella kontrastilla verrattiin valkuaistäydennyksen laadun (tavanomainen vs. ureapitoinen) vaikutusta (WCBRSM vs. WCBU).

\section{Tulokset ja tulosten tarkastelu \\ Rehujen koostumus}

Koerehujen kemialliset koostumukset ja rehuarvot on esitetty taulukossa 1 . Kokeessa käytetty nurmisäilörehu oli ravitsemukselliselta koostumukseltaan hyvälaatuista. Kuiva-ainepitoisuus oli keskimäärin $255 \mathrm{~g} / \mathrm{kg}$ ja D-arvo $678 \mathrm{~g} / \mathrm{kg}$ ka. Nurmisäilörehussa oli muuntokelpoista energiaa 10,8 MJ/kg ka, raakavalkuaista $151 \mathrm{~g} / \mathrm{kg}$ ka ja NDF-kuitua $581 \mathrm{~g} / \mathrm{kg}$ ka. OIV-pitoisuus oli keskimäärin $82 \mathrm{~g} / \mathrm{kg}$ ka ja PVT-arvo 29 g/kg ka. Nurmisäilörehu oli käymislaadultaan hyvää (Taulukko 1).

Taulukko 1. Koerehujen kemiallinen koostumus ja rehuarvot.

\begin{tabular}{lccccc} 
& Nurmisäilörehu & Ohrakokoviljasäilörehu & Ohra & Krono35 & Krono45 \\
\hline Näytemäärä, kpl & 13 & 13 & 4 & 4 & 4 \\
Kuiva-aine (ka), g/kg & 255 & 462 & 892 & 875 & 875 \\
Orgaaninen aine, g/kg ka & 931 & 932 & 976 & 915 & 918 \\
Raakavalkuainen, g/kg ka & 151 & 105 & 132 & 328 & 452 \\
NDF, g/kg ka & 581 & 484 & 197 & 283 & 285 \\
Raakarasva, g/kg ka & 45 & 20 & 18 & 36 & 47 \\
Tärkkelys, g/kg ka & 9 & 182 & 564 & 32 & 65 \\
Muuntokelpoinen energia, MJ/kg ka & 10,8 & 9,7 & 13,1 & 11,6 & 10,6 \\
OIV, g/kg ka & 82 & 72 & 98 & 160 & 135 \\
PVT, g/kg ka & 29 & -19 & -16 & 128 & 270 \\
D-arvo, g/kg ka & 678 & 623 & & & \\
Säilörehun syönti-indeksi & 98 & 114 & & \\
Säilörehun ME-indeksi & 99 & 100 & & \\
Säilörehujen säilönnällinen laatu & & & & \\
pH & 4,05 & 4,41 & & \\
Haihtuvat rasvahapot, g/kg ka & 18 & 5 & & \\
Maito- ja muurahaishappo, g/kg ka & 49 & 19 & & \\
Sokerit, g/kg ka & 45 & & & \\
Kokonaistypestä, g/kg & 60 & 386 & & \\
Ammoniumtyppi & & & & \\
Liukoinen typpi & 482 & & & \\
\hline
\end{tabular}

Kokeessa käytetty kokoviljasäilörehu oli selvästi kuivempaa kuin nurmisäilörehu (Taulukko 1). Kokoviljasäilörehun raakavalkuaispitoisuus oli $30 \%$ ja NDF-pitoisuus $17 \%$ matalampi kuin nurmisäilörehulla. Kokoviljasäilörehun energia-arvo oli $10 \%$ heikompi kuin nurmisäilörehulla. Säilönnälliseltä 
laadultaan kokoviljasäilörehu oli hyvää. Kokeessa käytetyn rehuohran kuiva-ainepitoisuus oli keskimäärin $892 \mathrm{~g} / \mathrm{kg}$, ohrassa oli muuntokelpoista energiaa 13,1 MJ/kg ka ja raakavalkuaista $132 \mathrm{~g} / \mathrm{kg} \mathrm{ka}$. Ohran OIV-pitoisuus oli keskimäärin $98 \mathrm{~g} / \mathrm{kg}$ ka ja PVT-arvo -16 g/kg ka.

Kokeessa käytettyjen seosrehujen keskimääräiset laskennalliset koostumukset ja rehuarvot on esitetty taulukossa 2. Krono 35 ja Krono 45 -tiivisteitä sisältäneiden seosten (WCBRSM ja WCBU) raakavalkuaispitoisuus oli keskimäärin $17 \%$ korkeampi kuin WCB-seoksen. WCB-seoksen PVT-arvo (-18 g/kg ka) oli nykyisiä suomalaisia lihanautojen ruokintasuosituksia alemmalla tasolla, sillä virallisten suositusten mukaan yli $200 \mathrm{~kg}$ painavien sonnien ja hiehojen valkuaisen saanti on riittävä, kun rehuannoksen pötsin valkuaistase eli PVT on yli $-10 \mathrm{~g} / \mathrm{kg}$ ka (MTT 2012). Valkuaistiivistetäydennys nosti WCBRSM ja WCBU -seosten PVT-arvon nykysuositusten mukaiselle tasolle (Taulukko 2). Valkuaistiivisteitä sisältäneissä seoksissa oli vähemmän tärkkelystä kuin WCB-seoksessa. Nurmisäilörehuseokseen verrattuna kokoviljasäilörehuseokset sisälsivät vähemmän energiaa ja kuitua mutta enemmän tärkkelystä (Taulukko 2).

Taulukko 2.Koeruokintojen kemiallinen koostumus ja rehuarvot.

\begin{tabular}{lcccc} 
Ruokinta & GS & WCB & WCBRSM & WCBU \\
\hline Kuiva-aine (ka), g/kg & 357 & 572 & 572 & 572 \\
Orgaaninen aine, g/kg ka & 949 & 950 & 944 & 946 \\
Raakavalkuainen, g/kg ka & 143 & 116 & 133 & 138 \\
NDF, g/kg ka & 427 & 369 & 377 & 375 \\
Raakarasva, g/kg ka & 34 & 19 & 21 & 21 \\
Tärkkelys, g/kg ka & 280 & 335 & 287 & 300 \\
Muuntokelpoinen energia, MJ/kg ka & 11,7 & 11,1 & 10,9 & 10.9 \\
OIV, g/kg ka & 88 & 82 & 88 & 85 \\
PVT, g/kg ka & 11 & -18 & -5 & 3 \\
\hline
\end{tabular}

GS = karkearehuna nurmisäilörehu, ei valkuaislisää.

WCB = karkearehuna ohrakokoviljasäilörehu, ei valkuaislisää.

WCBRSM = karkearehuna ohrakokoviljasäilörehu, valkuaislisänä rypsi (Krono 35).

WCBU = karkearehuna ohrakokoviljasäilörehu, valkuaislisänä rypsi + urea (Krono 45).

\section{Ruokintojen sulavuus}

Sekä dieetin kuiva-aineen että orgaanisen aineen sulavuuskertoimet olivat nurmisäilörehuruokinnalla noin $7 \%$ suuremmat kuin kokoviljasäilörehuruokinnoilla (Taulukko 3). Ero aiheutui erityisesti kuidun heikosta sulavuudesta kokoviljasäilörehuruokinnoilla, mikä on yhdenmukainen tulos monien aikaisempien kokoviljasäilörehuilla toteutettujen ruokintakokeiden kanssa (Walsh ym. 2008, Huuskonen \& Joki-Tokola 2010). On kuitenkin syytä huomata, että ruokintojen väliset erot kuiva-aineen ja orgaanisen aineen in vivo -sulavuuksissa olivat selvästi pienemmät kuin ruokintojen väliset erot kuidun sulavuudessa (Taulukko 3). Tämä kertoo siitä, että kokoviljasäilörehun sisältämä tärkkelys yhdessä tärkkelyksen korkean sulavuuden kanssa pystyy jonkin verran kompensoimaan kuitufraktion heikompaa sulavuutta suhteessa nurmisäilörehuun. Tärkkelyksen korkeat sulavuuskertoimet kertovat siitä, että suurin osa kokoviljasäilörehujen sisältämistä jyvistä tuli hajotettua ruoansulatuskanavassa eivätkä ne kulkeutuneet kokonaisina tai vain osaksi sulaneina ruoansulatuskanavan läpi.

Kokoviljasäilörehuruokintojen välillä ei ollut keskinäisiä eroja kuiva-aineen, orgaanisen aineen, kuidun eikä tärkkelyksen sulavuuskertoimissa (Taulukko 3). Sen sijaan raakavalkuaisen sulavuudessa oli merkitseviä eroja ruokintaryhmien välillä. Valkuaistäydennystä saaneilla ruokinnoilla (WCBRSM ja WCBU) raakavalkuaisen sulavuuskerroin oli suurempi kuin WCB-ruokinnalla. Lisäksi WCBRSMruokinnalla raakavalkuaisen sulavuuskerroin oli noin $9 \%$ suurempi kuin WCBU-ruokinnalla. Myös monissa aiemmissa tutkimuksissa dieetin raakavalkuaisen sulavuus on parantunut lisävalkuaista annettaessa (Huuskonen 2009, Huuskonen 2011). Parempi raakavalkuaisen sulavuus selittyy osin rypsin valkuaisen hyvällä sulavuudella, mutta osa siitä on pelkästään näennäistä. Esimerkiksi Huhtanen ym. (1989) raportoivat raakavalkuaisen näennäisen sulavuuden parantuneen valkuaislisää tarjottaessa. Tutkimuksessa kuitenkin todettiin, että typpeä erittyi virtsaan enemmän lisävalkuaista annettaessa.

\section{Rehun syönti ja ravintoaineiden saanti}

Sonnien kokonaiskuiva-aineensyönti oli kokeen aikana keskimäärin 10,11 kg/pv eikä ruokintaryhmien välillä ollut eroa kuiva-aineensyönnissä (Taulukko 3). Erot säilörehujen ravintoainesisällöissä näkyivät 
ruokintaryhmien ravintoaineiden saannissa (Taulukko 3). Energian, valkuaisen ja kuidun päivittäinen saanti oli nurmisäilörehuruokinnoilla selvästi kokoviljaruokintoja suurempaa. Nurmisäilörehua saaneilla sonneilla muuntokelpoisen energian päivittäinen saanti oli noin $8 \%$ suurempaa kuin kokoviljasäilörehua saaneilla sonneilla keskimäärin. Tärkkelyksen päivittäinen saanti oli kokoviljasäilörehuruokinnoilla nurmisäilörehuruokintaa suurempi.

Kokoviljasäilörehuryhmien välillä ei ollut eroa päivittäisessä energian saannissa, mutta valkuaistäydennystä saaneilla ruokinnoilla raakavalkuaisen ja PVT:n saanti oli merkitsevästi suurempi kuin WCB-ruokinnalla (Taulukko 3). Vastaavasti tärkkelyksen saanti oli WCB-ruokinnalla korkeammalla tasolla kuin valkuaistäydennystä saaneilla ruokinnoilla. Valkuaistäydennystä saaneiden ruokintojen (WCBRSM ja WCBU) välillä oli eroa ainoastaan OIV:n ja PVT:n saantien osalta. WCBRSMsonneilla OIV:n saanti oli noin $4 \%$ suurempi $(p=0.13)$ kuin WCBU-sonneilla. PVT:n saanti oli puolestaan WCBU-sonneilla WCBRSM-sonneja suurempaa.

Taulukko 3. Sulavuuskertoimet, rehun syönti ja ravintoaineiden saanti.

\begin{tabular}{lcccccccc} 
Ruokinta & GS & WCB & WCBRSM & WCBU & SEM & \multicolumn{3}{c}{ Kontrastit } \\
\hline Sulavuuskertoimet & & & & & & 1 & 2 & 3 \\
Kuiva-aine & & & & & & & & \\
Orgaaninen aine & 0,768 & 0,722 & 0,719 & 0,714 & 0,0079 & $<0,001$ & 0,58 & 0,70 \\
Raakavalkuainen & 0,750 & 0,739 & 0,737 & 0,733 & 0,0080 & $<0,001$ & 0,68 & 0,70 \\
NDF & 0,738 & 0,536 & 0,768 & 0,705 & 0,0098 & 0,02 & $<0,001$ & $<0,001$ \\
Tärkkelys & 0,988 & 0,954 & 0,519 & 0,526 & 0,0125 & $<0,001$ & 0,38 & 0,70 \\
& & & & 0,959 & 0,0041 & $<0,001$ & 0,57 & 0,45 \\
Syönti & & & & & & & & \\
Säilörehu, kg ka/pv & 5,84 & 5,84 & 5,77 & 5,71 & 0,132 & 0,66 & 0,51 & 0,75 \\
Väkirehu, kg ka/pv & 4,34 & 4,34 & 4,39 & 4,22 & 0,088 & 0,83 & 0,74 & 0,20 \\
Yhteensä, kg ka/pv & 10,18 & 10,19 & 10,16 & 9,93 & 0,219 & 0,72 & 0,60 & 0,48 \\
Energia, MJ/pv & 120 & 113 & 112 & 109 & 2,4 & 0,006 & 0,42 & 0,40 \\
Raakavalkuainen, g/d & 1495 & 1207 & 1290 & 1286 & 27,1 & $<0,001$ & 0,02 & 0,93 \\
OIV, g/pv & 902 & 843 & 883 & 836 & 16,7 & 0,02 & 0,42 & 0,06 \\
PVT, g/pv & 140 & -144 & -72 & -25 & 3,2 & $<0,001$ & $<0,001$ & $<0,001$ \\
NDF, g/pv & 4238 & 3679 & 3693 & 3622 & 81,5 & $<0,001$ & 0,83 & 0,54 \\
Tärkkelys, g/pv & 2492 & 3514 & 3240 & 3218 & 72,7 & $<0,001$ & 0,003 & 0,83 \\
\hline
\end{tabular}

GS = karkearehuna nurmisäilörehu, ei valkuaislisää.

WCB = karkearehuna ohrakokoviljasäilörehu, ei valkuaislisää.

WCBRSM = karkearehuna ohrakokoviljasäilörehu, valkuaislisänä rypsi (Krono 35).

WCBU = karkearehuna ohrakokoviljasäilörehu, valkuaislisänä rypsi + urea (Krono 45).

SEM = Keskiarvon keskivirhe.

Kontrastit: 1 = GS vs. muut, 2 = WCB vs. WCBRSM +WCBU, 3 = WCBRSM vs. WCBU.

\section{Kasvu ja rehun hyväksikäyttö}

Sonnit painoivat ruokintakokeen alussa keskimäärin $265 \mathrm{~kg}$, eikä ruokintaryhmien välillä ollut eroa kokeen alkupainoissa (Taulukko 4). Eläimet teurastettiin 562 vuorokauden ikäisinä, jolloin niiden elopaino oli keskimäärin $675 \mathrm{~kg}$. Teurastusiässä ei ollut eroa ruokintaryhmien välillä, mutta nurmisäilörehusonnien elopaino kokeen lopussa oli noin $4 \%$ suurempi kuin kokoviljasäilörehusonneilla keskimäärin. Nurmisäilörehusonnien teuraspaino $(356 \mathrm{~kg}$ ) oli noin $5 \%$ suurempi kuin kokoviljasäilörehusonneilla keskimäärin (338 kg). Sen sijaan kokoviljasäilörehuryhmien välillä ei ollut keskinäisiä eroja kokeen lopun elopainossa eikä teuraspainossa (Taulukko 4).

Sonnien päiväkasvu oli nurmisäilörehupohjaisella ruokinnalla noin $6 \%$ ja nettokasvu noin $8 \%$ parempi kuin kokoviljasäilörehupohjaisilla ruokinnoilla keskimäärin. Kasvuerot olivat todennäköisesti seurausta nurmisäilörehusonnien suuremmasta päivittäisestä energian saannista, joka puolestaan selittyy kokoviljasäilörehun nurmisäilörehua heikommalla sulavuudella. Havaitut kasvuerot vastaavat hyvin eroa sonnien päivittäisessä energian saannissa. Aikaisemmissa kokoviljasäilörehuilla tehdyissä lihanautojen kasvatuskokeissa (O'Kiely \& Moloney 1999, O'Kiely \& Moloney 2002, Keady ym. 2007, Walsh ym. 2008, Huuskonen \& Joki-Tokola 2010, Keady ym. 2013) on havaittu hyvin vaihtelevia kasvutuloksia suhteessa kulloinkin verrokkina käytettyyn nurmisäilörehuun. Esimerkiksi vehnäko- 
koviljasäilörehun lisääminen rehuannokseen on heikentänyt (O'Kiely \& Moloney 1999), parantanut (O’Kiely \& Moloney 2002) tai sillä ei ole ollut vaikutusta (Keady ym. 2007) lihanautojen kasvuun. Kasvuvasteet ovatkin riippuvaisia sekä kontrolliruokintana käytetyn nurmisäilörehun että tutkitun kokoviljasäilörehun ravitsemuksellisesta ja säilönnällisestä laadusta. Tässä raportoidussa tutkimuksessa kontrolliruokintana käytetty nurmisäilörehu oli hyvälaatuista, jolloin kokoviljasäilörehuruokinnoilla saavutetut kasvutulokset jäivät sitä heikommalle tasolle. On kuitenkin syytä huomata, että myös kokoviljasäilörehuruokinnoilla saavutettiin tässä tutkimuksessa hyvät kasvutulokset (nettokasvu keskimäärin $618 \mathrm{~g} / \mathrm{pv}$ ) moniin aikaisempiin ruokintakokeisiin (Huuskonen \& Joki-Tokola 2010, Huuskonen 2011) ja valtakunnallisiin keskiarvolukuihin (Herva ym. 2009) verrattuna.

Kokoviljasäilörehuruokintojen keskinäisissä vertailuissa kasvutuloksissa ei ollut eroja (Taulukko 4). Lisääntynyt raakavalkuaisen saanti ja dieetin korkeampi PVT-arvo valkuaistäydennystä saaneilla ruokinnoilla suhteessa WCB-ruokintaan ei realisoitunut parempina kasvuvasteina huolimatta siitä, että WCB-seoksen PVT-arvo oli nykyisiä suomalaisia lihanautojen ruokintasuosituksia alemmalla tasolla. Tämän tutkimuksen tulosten perusteella maitorotuisten sonnien valkuaisen saanti on riittävä, kun rehuannoksen PVT on yli -20 g/kg ka ja dieetin raakavalkuaispitoisuus yli $110 \mathrm{~g} / \mathrm{kg} \mathrm{ka}$.

Heikommista kasvutuloksista johtuen kokoviljaviljasäilörehuryhmien rehuhyötysuhde jäi nurmisäilörehuryhmää heikommaksi (Taulukko 4). Samoin muuntokelpoisen energian hyväksikäyttö kasvuun oli kokoviljasäilörehuryhmillä nurmisäilörehuryhmää heikompaa. Kokoviljasäilörehuryhmien välillä ei ollut merkitseviä eroja rehun hyväksikäyttöä kuvaavissa muuttujissa.

Taulukko 4. Kasvu- ja teurastulokset sekä rehun hyväksikäyttö.

\begin{tabular}{|c|c|c|c|c|c|c|c|c|}
\hline Ruokinta & GS & WCB & WCBRSM & WCBU & SEM & \multicolumn{3}{|c|}{ Kontrastit } \\
\hline & & & & & & 1 & 2 & 3 \\
\hline Ikä teurastettaessa, vrk & 561 & 563 & 562 & 561 & 3,5 & 0,81 & 0,79 & 0,80 \\
\hline Alkupaino, kg & 267 & 262 & 266 & 266 & 2,9 & 0,63 & 0,28 & 0,89 \\
\hline Loppupaino, kg & 695 & 671 & 667 & 666 & 12,1 & 0,06 & 0,74 & 0,98 \\
\hline Teuraspaino, kg & 356 & 339 & 339 & 336 & 6,6 & 0,03 & 0,87 & 0,77 \\
\hline \multicolumn{9}{|l|}{ Kasvu } \\
\hline Päiväkasvu, g/pv & 1252 & 1193 & 1173 & 1175 & 33,1 & 0,07 & 0,64 & 0,96 \\
\hline Nettokasvu, g/pv & 666 & 620 & 620 & 613 & 18,6 & 0,03 & 0,85 & 0,80 \\
\hline \multicolumn{9}{|l|}{ Teurastulokset } \\
\hline Teurasprosentti, g/kg & 512 & 505 & 509 & 505 & 4,6 & 0,26 & 0,73 & 0,57 \\
\hline Lihakkuus & 5,0 & 4,4 & 4,5 & 4,8 & 0,20 & 0,06 & 0,41 & 0,37 \\
\hline Rasvaisuus & 3,3 & 2,8 & 2,7 & 2,8 & 0,14 & 0,003 & 0,89 & 0,82 \\
\hline \multicolumn{9}{|l|}{ Rehun hyväksikäyttö } \\
\hline kg ka/nettokasvu-kg & 15,02 & 16,54 & 16,51 & 17,18 & 0,691 & 0,04 & 0,72 & 0,50 \\
\hline $\mathrm{MJ} /$ nettokasvu-kg & 167 & 189 & 185 & 195 & 7,7 & 0,02 & 0,90 & 0,38 \\
\hline
\end{tabular}

GS = karkearehuna nurmisäilörehu, ei valkuaislisää.

WCB = karkearehuna ohrakokoviljasäilörehu, ei valkuaislisää.

WCBRSM = karkearehuna ohrakokoviljasäilörehu, valkuaislisänä rypsi (Krono 35).

WCBU = karkearehuna ohrakokoviljasäilörehu, valkuaislisänä rypsi + urea (Krono 45).

SEM = Keskiarvon keskivirhe.

Kontrastit: 1 = GS vs. muut, 2 = WCB vs. WCBRSM +WCBU, 3 = WCBRSM vs. WCBU.

\section{Teurastulokset}

Koesonnien teurasprosentti oli keskimäärin $508 \mathrm{~g} / \mathrm{kg}$ eikä koeryhmien välillä ollut merkitseviä eroja teurasprosentissa (Taulukko 4). Ruhojen lihakkuuden osalta nurmisäilörehusonnit luokittuivat $9 \%$ paremmin kuin kokoviljaruokinnoilla olleet sonnit keskimäärin $(p=0,06)$, mutta kokoviljasäilörehuryhmien välillä ei ollut merkitseviä eroja ruhojen lihakkuudessa. Nurmisäilörehua saaneiden sonnien ruhot olivat keskimäärin 19 \% rasvaisempia kuin kokoviljasäilörehua saaneiden sonnien ruhot. Kokoviljasäilörehuryhmien välillä ei ollut eroja ruhojen rasvaisuudessa. Tutkimuksessa havaittu kokoviljasäilörehuryhmien heikompi lihakkuus ja vähäisempi rasvoittuminen voivat osittain selittyä kokoviljasonnien nurmisäilörehusonneja matalammalla teuraspainolla, sillä tutkimuksissa on havaittu teuraspainon olevan positiivisesti korreloitunut lihakkuuden (Kempster ym. 1988) ja rasvaisuuden (Keane \& Allen 1998) kanssa. Myös erot dieettien energiapitoisuuksissa voivat selittää eroja ruhojen luokituksissa, sillä ruokinnan energiaväkevyyden noustessa myös ruhon rasvaisuus ja lihakkuus yleensä lisäänty- 
vät (Herva ym. 2011). Valkuaistäydennyksellä ei havaittu olevan vaikutusta mihinkään ruhon laatua kuvaavista muuttujista (teuraspaino, teurasprosentti, lihakkuus, rasvaisuus). Myös kirjallisuuden perusteella valkuaislisän vaikutukset ruhon koostumukseen ovat yleensä olleet hyvin vähäisiä (Huuskonen 2009, Huuskonen 2011, Manninen ym. 2011).

\section{Yhteenveto ja johtopäätökset}

Sonnien kasvutulokset olivat nurmisäilörehupohjaisella ruokinnalla 6-8 \% paremmat kuin kokoviljasäilörehupohjaisilla ruokinnoilla. Myös kokoviljasäilörehuruokinnoilla saavutettiin tässä tutkimuksessa hyvät kasvutulokset (nettokasvu keskimäärin 618 g/pv), mikä osoittaa kokoviljasäilörehun olevan varteenotettava vaihtoehto lihanautatilan rehuviljelyssä. Valkuaistäydennys ei parantanut sonnien kasvua kokoviljasäilörehupohjaisella ruokinnalla. Lisääntynyt raakavalkuaisen saanti ja dieetin korkeampi PVT-arvo valkuaistäydennystä saaneilla ruokinnoilla ei realisoitunut parempina kasvuvasteina huolimatta siitä, että ilman valkuaislisää kokoviljasäilörehuruokinnan PVT-arvo oli nykyisiä suomalaisia lihanautojen ruokintasuosituksia alemmalla tasolla. Tämän tutkimuksen tulosten perusteella maitorotuisten sonnien valkuaisen saanti on riittävä, kun rehuannoksen PVT on yli $-20 \mathrm{~g} / \mathrm{kg} \mathrm{ka} \mathrm{ja} \mathrm{diee-}$ tin raakavalkuaispitoisuus yli $110 \mathrm{~g} / \mathrm{kg} \mathrm{ka}$.

\section{Kirjallisuus}

EC 2006. Council Regulation (EC) No 1183/2006 of 24 July 2006 concerning the Community scale for the classification of carcasses of adult bovine animals. The Official Journal of the European Union L, 214: 1-6.

Herva, T., Huuskonen, A., Virtala, A.-M. \& Peltoniemi, O. 2011. On-farm welfare and carcass fat score of bulls at slaughter. Livest. Sci. 138: 159-166.

Herva, T., Virtala, A.-M., Huuskonen, A., Saatkamp, H.W. \& Peltoniemi, O. 2009. On-farm welfare and estimated daily carcass gain of slaughtered bulls. Acta Agric. Scand., Sect. A, Anim. Sci. 59: 104-120.

Huhtanen, P., Nousiainen, J. \& Rinne, M. 2006. Recent developments in forage evaluation with special reference to practical applications. Agric. Food Sci. 15: 293-323.

Huhtanen, P., Näsi, M. \& Khalili, H. 1989. By-products from integrated starch-ethanol production from barley in the diets of growing cattle. J. Agric. Sci. Finl. 61: 451-462.

Huuskonen, A. 2009. The effect of cereal type (barley versus oats) and rapeseed meal supplementation on the performance of growing and finishing dairy bulls offered grass silage-based diet. Livest. Sci. 122: 53-62.

Huuskonen, A. 2011. Effects of barley grain compared to commercial concentrate or rapeseed meal supplementation on performance of growing dairy bulls offered grass silage-based diet. Agric. Food Sci. 20: 191-205.

Huuskonen, A. \& Joki-Tokola, E. 2010. Performance of growing dairy bulls offered diets based on silages made of whole-crop barley, whole-crop wheat, hairy vetch and grass. Agric. Food Sci. 19: 116-126.

Keady, T.W.J., Hanrahan, J.P., Marley, C.L. \& Scollan, N.D. 2013. Production and utilization of ensiled forages by beef cattle, dairy cows, pregnant ewes and finishing lambs: a review. Agric. Food Sci. 22: 70-92.

Keady, T.W., Lively, F.O., Kilpatrick, D.J. \& Moss, B.W. 2007. Effects of replacing grass silage with either maize or whole-crop wheat silages on the performance and meat quality of beef cattle offered two levels of concentrates. Animal 1: 613-623.

Keane, M.G. \& Allen, P. 1998. Effects of production system intensity on performance, carcass composition and meat quality of beef cattle. Livest. Prod. Sci. 56: 203-214.

Kempster A.J., Cook G.L. \& Southgate J.R. 1988. Evaluation of British Friesian, Canadian Holstein and beef breed $\times$ British Friesian steers slaughtered over a commercial range of fatness from 16-month and 24-month beef production systems. 2. Carcass characteristics, and rate and efficiency of lean gain. Anim. Prod. 46: 365-378.

Manninen, M., Honkavaara, M., Jauhiainen, L., Nykänen, A. \& Heikkilä, A-M. 2011. Effects of grass-red clover silage digestibility and concentrate protein concentration on performance, carcass value, eating quality, and economy of finishing Hereford-bulls reared in cold conditions. Agric. Food Sci. 20: 151-168.

Moisio, T. \& Heikonen, M. 1989. A titration method for silage assessment. Anim. Feed Sci. Technol. 22: 341353.

MTT. 2012. Rehutaulukot ja ruokintasuositukset. Maa- ja elintarviketalouden tutkimuskeskus. Verkkojulkaisu. Saatavissa internetistä: https://portal.mtt.fi/portal/page/portal/Rehutaulukot

O'Kiely, P. \& Moloney, A.P. 1999. Whole crop wheat silage for finishing beef heifers. Ir. J. Agric. Food Res. 38: 296 (Abstract).

O'Kiely, P. \& Moloney, A.P. 2002. Nutritive value of whole crop wheat and grass silage for beef cattle when offered alone or in mixtures. Proceedings of the Agricultural Research Forum. s. 42.

Walsh, K., O'Kiely, P., Moloney, A.P. \& Boland, T.M. 2008. Intake, performance and carcass characteristics of beef cattle offered diets based on whole-crop wheat or forage maize relative to grass silage or ad libitum concentrates. Livest. Sci. 116: 223-236. 